\title{
China-Africa Cooperation: Joint Engagement in Adaptation to Climate Change
}

Wanxin Li, Sven Grimm \& Harrie Esterhuyse

\section{Abstract}

China's economic success since the 1990s has been staggering. With its economic growth, the country has experienced new challenges, particularly with regard to environmental sustainability on the one hand, and increasing international demands and responsibilities on the other. Climate change is a key issue for both these challenges. This article explores the rise of environmental concerns, particularly climate change, on the domestic policy agenda in China, and the issue of greening China's growth. Domestic policies and their challenges are the background against which the article investigates the potential and limitations of international engagement in the mitigation of, and adaptation to, climate change. International challenges are discussed in the second part of the article, which looks into the negotiations on actions to mitigate and manage climate change, and specifically the support China has received regarding adaptation to climate change within the China-Africa cooperation platform. In the context of this cooperation, renewable energy, among other things, offers the potential for a viable solution for Africa's energy deficiency, specifically as regards electricity. This cooperation is still in the early stages. Therefore, this article looks at the potential in the relationship rather than at specific actions.

\section{A. Introduction}

China's economic development has been one of the big global development success stories of the last generation. China's gross national income has grown tenfold over the past 25 years. Given China's size as well as its demographic weight, this impressive economic growth is a basis for global 
political weight. ${ }^{1}$ After having pursued the Reform and Opening Up Poli$\mathrm{cy}^{2}$ proposed by Xiaoping Deng in 1978 , China has increasingly been 'going out' since the late 1990s - not least so by engaging with and investing in other Asian countries and Africa. Under President Hu Jintao, the country has been engaging more and more in global politics, including more cooperation with African states. Environmental policies increasingly form part of the country's external political agenda, for both domestic and international reasons.

In recent decades, the rapid development growth path in the major emerging economies such as Brazil, China, India and Russia has been accompanied by severe environmental degradation. ${ }^{3}$ In China itself, development is happening at breathtaking speed. The challenges, which include land use, water pollution, air quality and, of course, climate change, are manifold. China's economic growth has led to numerous environmental problems that are being increasingly addressed by policymakers, not least because environmental pollution has reached a level that clearly comes with economic costs. ${ }^{4}$ Pollution today is a topic around which Chinese citizens organise and challenge state decisions. ${ }^{5}$ It might be a lesson learnt from the fall of the communist regimes in Central Europe that environmental pollution is one of the crystallising points for a dissident civil society if the complaints and immediate threats to citizens' health and well-being are not addressed by the state.

Climate change and the required adaptations to it clearly constitute a double challenge for emerging powers like China, as they step up their global engagement and their struggle with environmental damage at home. China is home to the world's ten most polluted cities. In $2007,46 \%$ of the global coal production was mined in China, and used for the generation of electricity. The 2.5 billion $t$ of coal, however, were not sufficient for China's entire domestic consumption needs, and in 2007 the country became a net coal importer. ${ }^{6}$ Energy demand in China is still on a steep increase, with more strain on global resources to be expected, given that China is still in a

1 Kaplinsky \& Messner (2008).

2 The nature of the economy has changed from a centrally planned system under rigid political control to a more market-oriented economy that has a rapidly growing private sector and is a major player in the global economy.

3 Shaw (2012).

4 World Bank (2007); Economy (2007).

5 Li et al. (2012); Chen (2009:xxi); Burgess (2012).

6 Zhu (2010:2). 
catching-up phase of development. In this agenda of economic priorities with immediate pollution problems, climate change is a rather complex and abstract issue, yet one that is high on the international agenda. There are, nonetheless, linkages between combating some of the pollution problems in China and working to mitigate climate change. China's 12th Five-year Plan (2011-2015) attributes high importance to environmental investments, such as renewable energy (for mobility and electricity), and biotechnology. Addressing environmental challenges, including climate change, has been rationalised in China as both necessary for solving domestic problems, and important due to its potential to gain new business opportunities and competitive advantages.

At the international level, China has also indicated the importance of sustainable development and renewable energy in its relationship with Africa. New institutions have been created in the interests of China-Africa relations, such as the Forum on China-Africa Cooperation (FOCAC), and economic cooperation has skyrocketed in the last decade. ${ }^{7}$ As a Chinese business participant in South Africa enthusiastically stated at a Centre for Chinese Studies workshop in Stellenbosch, South Africa, in August 2011, "China will change the face of this continent". ${ }^{8}$

It is, in fact, very likely that China's economic growth will change the global political, economic and ecological balance. The Chinese government may be more cautious in the presentation of its influence, but there is little doubt that China's developmental rise not only influences the global situation, it also directly impacts on development prospects in Africa.

Immediate environmental challenges exist on the African continent. Large-scale environmental pollution in the Niger Delta is one example for already existing environmental troubles: oil extraction that comes with substantial pollution results in little to no developmental gains for the affected communities. This is one of the prime examples of ignorance towards the ecology and people's livelihoods as a driver for conflict. ${ }^{9}$ Compared with the existing local challenges, climate change is more abstract, but no less threatening. The global change in climate is being felt in Africa today already, leading to further development problems on the African continent. The Chinese experiences with steep development gains at the expense of

7 Cissé (2012).

8 Statement during a Centre for Chinese Studies workshop, Stellenbosch University, August 2011.

9 See e.g. Obi (2008). 
nature might be an illustration of what is to be expected in the future, if African economic growth accelerates further. Global connectivity has increased in terms of trade and personal exchanges. Changing climate is expected to result in fundamental shifts in the livelihoods of African societies. These shifts will result in more potential for conflicts and challenges, such as the escalation of forced migration. ${ }^{10} \mathrm{With}$ regard to climate-change-related policy and mitigation of climate change, the global linkages are particularly obvious. Not least due to generally higher per capita carbon dioxide emissions (with the notable exception of South Africa), China has started to accept responsibility for assisting in the adaptation to climate change, as has been repeatedly stated in the declarations at the end of FOCAC meetings. Indeed, the Fifth FOCAC Action Plan (2013-2015) states that China and Africa actively support advancing cooperation in clean energy and renewable resource projects with the "ideals of mutual benefit and sustainable development". ${ }^{11}$

This article first looks at China's domestic policy activities and asks the question: Can China green its own growth? With the domestic policy emphasis and challenges in mind, the thrust and the limitations of China's international engagement in respect of mitigation and adaptation to climate change can be better understood. The focus in the second part of the article is on the international agenda regarding negotiations on measures to mitigate and adapt to climate change. This ultimately leads to questions of adaptation to climate change, specifically in the context of the China-Africa cooperation.

\section{B. Climate Issues Climbing in Importance on the Chinese Domestic Political Agenda}

In 2005, having realised the urgent need to improve the quality of China's economic growth, President $\mathrm{Hu}$ Jintao called for a scientific approach to development. In the same year, responding to the public call for environmental and social justice, the central government set the national objective of building a harmonious society. In 2006, riding the wave of environmental concern, the then State Environmental Protection Agency ${ }^{12}$ announced an

10 Ruppel \& Van Wyk (2011).

11 FOCAC (2012:section 4.6.3).

12 Upgraded to the Ministry of Environmental Protection (MEP) in 2008. 
environmentally adjusted gross domestic product (GDP) growth rate, aiming to alert provincial governments and the public to losses caused by pollution, as well as the danger of a single-minded pursuit of economic growth in China. Also in 2006, the State Council announced pollution reduction and energy efficiency targets in the 11th Five-year Plan (2006-2010), and local leaders were made accountable for meeting those targets.

In the context of international efforts to reduce carbon emissions, on 25 November 2009 at the 16th Conference of the Parties (COP16) in Copenhagen, Premier Wen Jiabao announced that, by 2020, China aimed to reduce its carbon emissions per unit of GDP by $40-45 \%$ from its 2005 level. ${ }^{13}$ Continuing the same trend, greater emphasis was placed on pollution control, energy efficiency and carbon reduction in the 12th Five-year Plan. Students of politics and the environment in China interpreted this as a signal that the central government was readjusting its focus from economic growth to environmental and social aspects that are relevant for people and their livelihoods. ${ }^{14}$

As observers have correctly pointed out, one of the leading themes in the 12th Five-year Plan is low-carbon development. The Plan includes an investment of $¥ 2.37$ billion into energy-saving projects, for example. It also aims to reduce energy consumption by $16 \%$ per $¥ 10,000$ by 2015 , using 2010 as the base year. A 30\% increase in clean energy generation year-on-year for each year running is another target. The following objectives are considered indispensable for achieving the ambitious transformation goals:

1. In the short term, adopting low-carbon technologies and controlling carbon emissions

2. In the medium term, upgrading industrial structure, decoupling economic growth and carbon emissions, and cultivating low-carbon consumption and lifestyles, and

3. In the long term, achieving improved resource efficiency, a healthier and more ecologically balanced environment, and harmony between humans and nature. ${ }^{15}$

Much attention has been paid to the co-benefits of carbon mitigation, i.e. upgrading technology, reducing pollution, offering a sustainable supply of energy and other resources, and improving the quality of life. China hosted

13 State Council (2009).

14 Editorial Report (2010).

15 Xiong (2011). 
almost half (45.72\%) of the global total of 3,447 Clean Development Mechanism (CDM) projects registered with the United Nations Framework Convention on Climate Change (UNFCCC) in 2011. Furthermore, cities such as Baoding have become more competitive in the global market regarding the production and export of solar panels. ${ }^{16}$ Despite no consensus having been reached within Chinese society, the central government has worked hard to mainstream the environment and a climate agenda in government decisionmaking.

Not only have policymakers seen the potential of these co-benefits, the business community has also been trying to develop this competitive edge in almost all sectors of economic life, e.g. in construction, urban planning, new energy technologies and products, and innovative instruments for financing low-carbon initiatives. For instance, engineers have successfully worked with the Guangzhou municipal government to build a zero carbon emission building - the Pearl River Tower. Urban planners have also successfully sold their ideas to cities in order to plan and build low-carbon districts/zones, as follows:

- Lile Island in Hainan Province

- The Shouan township in Chengdu

- The Yujiabao financial district in Tianji

- The Wangjiadun Green Central Business District in Wuhan, and

- Ten low-carbon townships in Huizhou, Guangdong Province.

New energy technologies are being sold both domestically and internationally, such as batteries for electric cars, fast-charging stations and solar panels. However, comparatively fewer companies are engaged in inventing financial instruments for funding low-carbon development. In June 2010, the China Beijing Environment Exchange established an investment platform for contractual power management. With the Chinese government starting to aggressively promote pilot low-carbon cities and counties in the 12th Fiveyear Plan period, it is expected that the energy industry will quickly seize business opportunities and come up with improved climate mitigation and adaptation policy to further develop competitiveness around these measures.

It is a given that business opportunities in the low-carbon development environment are largely dependent on government regulations and supportive initiatives which encourage the devising and deployment of environ- 
mental technologies that address climate change. To this end, the Chinese government has invested in environmental research and development (R\&D), e.g. Minister Wan Gang of the Ministry of Science and Technology indicated, on 12 November 2009 at the High-level Forum on Energy Efficiency and Pollution Reduction v Global Climate Change, that the Ministry of Science and Technology had invested over $¥ 10$ billion in developing technologies that addressed climate change. ${ }^{17}$

Furthermore, funds from private sources have been increasingly mobilised to match public investments in R\&D. Since 1981, the total number of national key technology $R \& D$ projects, as well as $R \& D$ funding from private sources, has greatly increased. Yet the share of funds from the central government has declined since 1981. During the 6th Five-year Plan period (1981-1985), the Ministry of Finance (MOF) in the central government contributed up to $60 \%$ of the total funds, while during the 10th Five-year Plan period (2001-2005), the share taken up by the MOF dropped to only $8.3 \%$. Thus, the central government has clearly changed its role from major funder to advisor and facilitator. ${ }^{18}$ More private investments have entered into energy- and carbon-related $R \& D$ in recent years, especially now that a global consensus has been built on the urgency of addressing climate change.

The deployment and adoption of environment-friendly technologies are as important as the development of environmental technologies. Industry experts generally agree that China's new energy industry is limited by the underdeveloped domestic application of new technologies. Official data show China's production of solar cells accounted for $50 \%$ of the world's total output in 2010; however, $95 \%$ of that output was exported. ${ }^{19}$

Another government priority entailed formulating tax incentives and subsidies at consumer level for those using environment-friendly products. In 2008 and 2009, for example, the MOF and the National Development and Reform Commission (NDRC) offered households a subsidy of up to $50 \%$ of the price of an energy-saving light bulb. ${ }^{20} \mathrm{~A}$ national collection system for used electronic home appliances was established in 2009. Logistic companies were employed by government to pick up used appliances and send them to certified waste-disposal companies. Furthermore, households were

17 Xinhua News Agency (2009).

18 OECD (2009).

19 Zhu (2011a).

20 MOF \& NDRC (2007). 
awarded with coupons which they could use when purchasing new electronic home appliances. ${ }^{21}$

The MOF also subsidises individuals who purchase electric vehicles. ${ }^{22}$ The city of Shenzhen, where the headquarters of the largest electric vehicle manufacturer, BYD, is located, provides matching funds of up to $¥ 50,000$ per vehicle to subsidise customers who purchase BYD electric vehicles. Other incentives are more indirect. Currently, a carbon tax is under consideration by the MOF and the NDRC, the latter having acquired green government procurement regulation that is hoped to also greatly boost the demand for green technologies and products. ${ }^{23}$

In addition, the Chinese government has devised measures to assist companies and individuals in making desirable environmental choices through information-sharing and capacity-building. The China Standard Certification Centre, for example, certifies and labels energy-efficient products. The Ministry of Environmental Protection and local governments rate the environmental performance of polluting firms using a colour-coded scale. This information is made publicly available. ${ }^{24}$ By implementing the Top- 1000 Energy-Consuming Enterprises Program, the NDRC is helping to build capacity in businesses in order to enhance energy efficiency.

\section{Can China Green its Own Growth? Challenges for China in Addressing Climate Change}

The fact that the Chinese government is paying increased attention to climate-change-related policy is reassuring, but it also begs the question of where obstacles or challenges remain. There are at least four broader areas that require increased attention in order to meet the domestic goals regarding environmental sustainability. These four are discussed individually below.

21 MOF et al. (2009).

22 MOF \& MOST (2009).

23 Xinhua News Agency (2009b).

24 Nature (2009). 


\section{Fragmented Government Structure}

China's fragmented government structure means that industrial, energy and innovation policies do not always coincide. There is no doubt that addressing climate change and realising its co-benefits have been widely accepted by the different levels of government, yet at the implementation of the 12th Five-year Plan, there were five different schemes funded by different ministries for developing low-carbon pilot and demonstration projects, as follows:

- 5 provinces and 8 cities chosen by the NDRC

- 108 counties chosen by the MOF, together with the Ministry of Agriculture and the National Energy Bureau

- 100 new energy-demonstration cities chosen by the NDRC

- Low-carbon transportation pilot cities chosen by the Ministry of Communication, and

- A low-carbon demonstration city, jointly built by local government and the Ministry of Housing and Urban-Rural Construction.

When local governments volunteer themselves to be part of one or more of these programmes, much productive time and many productive resources are lost in bureaucracy, e.g. preparing paperwork, or receiving delegations from different ministries that do not necessarily coordinate their travel plans. These examples show how the fragmented government structure is not necessarily conducive to coherence as regards industrial, energy and innovation policies. The challenge is, therefore, to come up with a coherent national strategy to address climate change.

\section{Weak Environmental Compliance and Enforcement}

Weak environmental compliance and enforcement is also not conducive to technological innovation and/or adoption of environmental policy. Even though China has devoted considerable resources to measures such as treatment facilities aimed at abating and controlling pollution, rapid industrialisation and urbanisation have outpaced efforts to clean up. The situation in this regard is even more complicated with local governments than it is with central government. This is partly due to the fact that provincial governors and county/city mayors are evaluated according to the GDP growth rates of their localities, irrespective of the impact of rapid growth on the local envi- 
ronment. Therefore, they tend not to take environmental or low-carbon growth objectives seriously. ${ }^{25}$ This is an example of how weak environmental compliance and enforcement has failed to reinforce technological innovation and/or policy adoption.

\section{Insufficient Incentives and Disincentives}

Insufficient incentives and disincentives are offered to enterprises to become green. Pollution discharge fees have been so low that it has made more economic sense for polluters to pollute rather than to attempting to avoid pollution or pay costs for treatment of polluted natural resources. According to one account, ${ }^{26}$ the operating cost of wastewater treatment in one high-polluting industry on average is around $¥ 1.2-1.8$ per ton. The fixed investment in a wastewater treatment facility is $¥ 100$ million for the 150 -t-per-day alkali recycling equipment used in the paper and pulp industry. Yet the maximum fine for wastewater discharge is $¥ 100,000$. Hence, it is a rational business choice to pay the fine rather than treat the pollution. ${ }^{27}$

\section{Lack of Social Infrastructure for Addressing Climate Change}

Not only is there a need for trust, consensus-building, social organising and collective action, there is also a lack of social infrastructure for addressing climate change at the local level. Access to environmental information, participation in environmental decision-making, and environmental justice has been limited. Furthermore, the root cause of local environmental degradation can often be attributed to the changing climate. Heightened public awareness of environmental degradation and increasing anxiety over health and property values drive people to fight for more political space to influence decisions that have an impact on the environment. Despite the promises made in the letter of Chinese law, Chinese society lacks a meaningful institutional framework to allow public participation in the area of environmental pro-

25 Tilt (2007); Zhu \& Ru (2008).

26 Yang \& Ge (2006).

27 (ibid.). 
tection. ${ }^{28}$ On the whole, the Chinese government only responds to public demands on an ad-hoc basis, with no institutional commitment to proactively engaging the public in environmental issues. ${ }^{29}$ Often, the public does not trust the government and/or business, which presents an immense challenge as regards addressing climate change because it requires collective action at the local level.

As far as global climate change is concerned, local and domestic action is urgently needed. On the other hand, the global challenge also requires global cooperation. In the next section we focus on the global dimension of China's climate change agenda.

\section{Global Engagement on Climate Change - Issues for International Negotiations}

On the global level, China has actively engaged with the climate regime. The country is a signatory of the Kyoto Protocol. On 2 September 2005, a bilateral Memorandum of Understanding on a European Union and China Partnership on Climate Change was signed. The Chinese and United States (US) heads of state initiated a Strategic Dialogue in 2005 as well as a biannual Strategic Economic Dialogue in 2006. In 2009, led by the US Departments of State and Energy and the Chinese NDRC, the two countries negotiated a Memorandum of Understanding to Enhance Cooperation on Climate Change, Energy and the Environment. China has also worked on a project basis with other developed countries. These include Switzerland, in the Sino-Swiss Low Carbon Cities in China project; and the United Kingdom (UK), in the China Climate Adaptation Project co-funded by the UK Department for International Development and the Swiss Agency for Development and Cooperation.

28 For example, the Beijing municipal government only started to make public the local concentration levels of particular matter smaller than 2.5 micrometres $\left(\mathrm{PM}_{2.5}\right)$ after the United States Embassy in Beijing published its monitoring data on $\mathrm{PM}_{2.5}$; see http://beijing.usembassy-china.org.cn/aqirecent3.html, last accessed The serious smog in January 2013 in Beijing and other parts of the country alarmed even the politically and economically powerful, as it affected all parts of the population, irrespective of their social status. Thus, a wider consensus was built on addressing environmental degradation and combating climate change.

29 Li et al. (2011). 
These activities have all been carried out in line with the following six principles, articulated by Xie Zhenhua of the NDRC: ${ }^{30}$

1. Addressing climate change under the framework of sustainable development

2. Common but differentiated responsibilities

3. Mitigation and adaptation are equally important

4. International Conventions and Protocols are the principal channel for addressing climate change at the global level

5. Emphasis on technological innovation and technology transfer, and

6. Wide public participation and international cooperation.

China has shown respect for the international climate regime and engages as a developing country. Members of the private sector in China have been participating in the CDM as beneficiaries of the transfer of funds and technology. China has hosted twice as many CDM projects as India, which has hosted the second largest number of CDM projects. This has put China in competition with other developing countries for international assistance.

For China, engaging with the post-Kyoto climate change regime is a challenge. Due to its status as a developing country, China is unlikely to accept a national cap on its carbon emissions in the years to come. However, as is stated in Chapter 21 of the 12th Five-year Plan, the country aims to construct a carbon inventory and institutionalise the calculation for developing carbon markets for all relevant activities. ${ }^{31}$ There are already five emissions exchanges - in Beijing, Chongqing, Shanghai, Shenzhen and Tianjin. The discussion on the inability of these exchanges to conduct business and launch pilot carbon emissions markets has largely concerned geographic issues, e.g. where to form such a market. Unfortunately, China has not yet formulated sectorial strategies to prepare for a global carbon emissions trading scheme. At a more basic level, for a carbon emissions trading scheme to work, countries have to agree on how many tons of carbon emitted they are responsible for. This introduces the methodological challenge of how to calculate carbon emissions: by production or by consumption. Researchers and policymakers do not agree on these issues, not least because oil production and global production chains for manufacturing result in carbon emissions outside the countries of consumption. China has emitted less

30 Xie et al. (2009).

31 State Council of China (2011). 
than a third of the carbon produced per capita, compared with developed countries. It is most likely that China would support the allocation of responsibility for carbon emissions on a consumption basis. However, China has not yet formulated a convincing methodology for calculating the life cycle of carbon emission footprints of resource extraction and industrial outputs, and may, therefore, miss opportunities to engage with other developing countries and the developed world.

\section{E. Adaptation to Climate Change in China-Africa Relations}

The relationship between China and Africa is often understood as being driven by China's resource needs, which includes fossil fuels from Africa. While China's dependence on fossil fuel imports will not be easily overcome, its endeavours to promote renewable energy also have an international dimension which is explored in this section with regard to China-Africa relations. As discussed above, for domestic reasons, China needs to upgrade its technology and increase its domestic production of renewable energies in order to reduce environmental pollution and mitigate climate change.

A renewed emphasis is placed on sustainable development and, by extension, renewable energy, in the Fifth FOCAC Action Plan:

- China pledges to increase the size of the China-Africa Development Fund to US\$5 billion ${ }^{32}$

- China commits to providing a US\$20 billion credit line to African countries for infrastructure development and for boosting sustainable development $^{33}$

- China promises to keep African interests in mind, stating that it wishes to assist African countries in raising the added value of resource products, while "protecting [the] local eco-environment and promoting ... sustainable economic and social development", 34 and

- China and Africa agree to strengthen cooperation in the area of infrastructure development, including in the generation of electricity and energy. ${ }^{35}$

32 FOCAC (2012:section 4.2.4).

33 (ibid.:section 4.5.2).

34 (ibid.:section 4.6.2).

35 (ibid.:section 4.6). 
China has pledged between US\$15 billion and US\$20 billion for sustainable development projects in Africa and is already investing US\$700 million in Guinea's rural electricity system. ${ }^{36}$ China has the expertise and the capital reserves to partner with Africa. The need and the plans for the expansion of electricity supply based on renewable energy are evident in Africa. For example, Ethiopia has plans for 150,000 home solar systems, 300 wind pumps, 300 solar pumps, 3,000 institutional photovoltaic systems, and three million solar lanterns, as well as measures to improve domestic use of biomass. ${ }^{37}$ Egypt, which features conditions that are of the best in the world for wind and solar power, is planning to increase energy production from renewable sources, including hydropower, to $20 \%$ in 2020 . Hydropower generation currently accounts for $12 \%$ of the energy mix, but this will decline to $8 \%$ by 2020 if no further investment is made. ${ }^{38}$ Thus, there is clearly a market for foreign investment in Africa - not least that of Chinese origin.

Strategies for Africa can use both on-grid solutions, such as making use of grid-connected, concentrated solar power stations, wind farms or hydropower stations, or small-scale, off-grid solutions, such as solar photovoltaic modules. The available technology lends itself to both rural and urban scenarios in Africa. Solar photovoltaics, in which technology the Chinese are particularly experienced and skilled, is especially promising as it can easily be installed as an off-grid solution in rural areas, where grid extension is very expensive.

Some African successes are encouraging. Ghana increased its population's electricity access from $25 \%$ in 1989 to $66 \%$ by 2011 , with rural access in particular having risen from $5 \%$ to $40 \%$ in the same period. ${ }^{39}$ South Africa increased its urban electrification from $30 \%$ in 1994 to $83 \%$ by 2011 , and rural electrification from $12 \%$ to $57 \%$ in the same period. ${ }^{40}$ With its Green Economy Accord, South Africa is also slowly turning towards more sustainable solutions. Although it is currently heavily reliant on coal-based power, it aims to increase its production of renewable energy, which has become much more affordable in recent years due to maturing markets and technologies.

36 (ibid.:section 4.5.2); IRENA (2011:7).

37 IRENA (2011:19).

38 (ibid.:18).

39 (ibid.:6).

40 (ibid.). 
Expertise is also required in the regulation of energy sectors, as energy and electricity generation faces political and regulatory shortcomings in African countries ${ }^{41}$ Regulatory frameworks need to be coherent and consistent, and need to incentivise the production of renewable energy over fossil fuels, including access to finance. They also need to address technical obstacles for on-grid solutions. Most of Africa's power supply at present is produced by government-backed utilities. Thus, governments will have to engage actively in maintaining and expanding the grid, as well as in promoting off-grid solutions, implementing regulatory frameworks that are conducive to the production and consumption of renewable energy and creating investment incentives. A mere liberalisation of energy production is unlikely to result in increases in the production of renewable energy.

\section{F. Conclusions}

Green growth requires conserving and increasing environmental and natural assets, and distributing the benefits of growth fairly throughout society to improve general well-being beyond economic growth, and without causing environmental harm. On 25 November 2009, Premier Wen Jiabao announced at COP16 in Copenhagen that, by 2020, China aimed to reduce its carbon emissions per unit of GDP by $40-45 \%$ from their 2005 levels. ${ }^{42}$ Continuing in this trend, increased emphasis was placed on pollution control, energy efficiency and carbon reduction in the 12th Five-year Plan. Short-, medium- and long-term objectives for achieving a transformation toward low-carbon development were outlined in Section B of this article. These new policy targets signalled a readjustment in focus by the central government, from economic growth to the environmental and social aspects relevant for people and their livelihoods. ${ }^{43}$ Together with a strong emphasis on social development during the 12th Five-year Plan, China is embracing the concept of green growth for a sustainable development path and a harmonious society. Therefore, Chinese society needs to incentivise government agencies, economic agents and civic organisations to articulate their pos-

41 See Lüdemann (2011).

42 State Council of China (2009).

43 Central Committee of the 17th National Congress of the Communist Party of China (2010). 
itions more effectively, as well as heed environmental and social interests in their decision-making.

In the context of the China-Africa relationship, including the FOCAC, renewable energy not only provides a viable solution for Africa's energy and, specifically, electricity - shortage, but it also has the potential to overcome obstacles in infrastructure development in Africa in the electricity sector, and alleviate the infrastructure shortage. In this context, the discussion in this article focused on the potential for action and benefits because cooperation on adaptation to climate change is still in its infancy. Small, offgrid solutions, such as solar photovoltaic modules, are best suited to rural areas. People in remote areas of Africa have long-standing experience with wind energy in the operation of pumps for wells. Current investment in wind energy for electricity is, however, rather an on-grid solution which may be more suitable for urban agglomerations. This is because peaks and valleys in consumption need to be balanced to maintain the stability of the electricity supply.

Small rather than large energy projects should be funded first, and they should be introduced gradually into rural areas, allowing for a learning curve. Decentralised options provided by renewables can provide rapid access to basic levels of electrification. In time, large-scale renewable projects can be introduced, such as concentrated solar and geothermal plants. China has the technology and capital for these investments. For these activities to be successful and to reduce the obstacles to renewable energy implementation, African governments will have to devote attention to national regulation and legislation and, most importantly, its implementation. The policy changes should include lower import tariffs on renewable energy equipment and opening up national electricity production to competition. African governments should also integrate renewable energy into their electricity production plans, which can be done through a tendering process, or by guaranteeing viable feed-in tariffs.

The investments required to foster renewable energy are high. There is, thus, a need for Africa and China, as well as African countries amongst themselves, to recognise a need for cooperation between the private and public sectors. Regional bodies such as the New Partnership for Africa's Development and international bodies such as FOCAC should also play a role in promoting renewable energy, e.g. by facilitating investments and enabling transfrontier solutions, where appropriate. Establishing regional energy bodies and consulting with the private sector in energy and electricity planning are important in this process. Energy trade across borders should 
be increased as well. Furthermore, stepping up regional integration by way of connected grids will enhance grid reliability and enlarge the available pool of skills in respect of grid maintenance.

As regards cooperative solutions, it is the task of African governments, as well as the responsibility of the China-Africa development partnership, to ensure that not only is technology provided for renewable energy installation, but also that the necessary technology transfer takes place. African states need to upgrade the skills that are essential to post-installation system maintenance and expansion. China-Africa agreements in the field of energy should, thus, include clear references to technology transfer.

\section{References}

Burgess, Meryl, 2012, Thick Air in Beijing - Air Pollution as a Political Issue, CCS Commentary, Stellenbosch, Centre for Chinese Studies, 2 April, available at http://w ww.ccs.org.za/wp-content/uploads/2012/04/Beijing-pollution-commentary-MB_fin al.pdf, last accessed 28 January 2012.

Central Committee of the 17th National Congress of the Communist Party of China, 2010, Suggestions by the Central Committee of the Communist Party of China on How to Make 12th Five-Year Plan (中共中央关于制定国民经济和社会发展第十二个五年 规划的建议), available at http://www.ndrc.gov.cn/125gh.pdf, last accessed 20 November 2010.

Chen, Gang, 2009, Politics of China's Environmental Protection: Problems and Progress, Singapore, World Scientific Publishing Co. Pte. Ltd.

Cissé, Daouda, 2012, FOCAC: Trade, Investments and Aid in China-Africa Relations, CCS Policy Brief, Stellenbosch, Centre for Chinese Studies, available at http://www .ccs.org.za/wp-content/uploads/2012/05/FOCAC_Policy-Briefing_tradeinvest_final .pdf, last accessed 28 January 2012.

Economy, Elizabeth, 2007, Environmental Governance: The Emerging Economic Dimension, in: Carter, Neil and Arthur P.J Mol (Eds), Environmental Governance in China, London/New York, Routledge, 23-41.

FOCAC/Forum on China Africa Cooperation, 2012, The Fifth Ministerial Conference of the Forum on China-Africa Cooperation Beijing Action Plan (2013-2015), available at http://www.focac.org/eng/z, last accessed 23 January 2013.

$\mathrm{Hu}$, Jintao, 2006, Development Cannot be Pursued at the Cost of Ecological Environment and Human Life, Xinhua Net, 29 March.

IRENA/International Renewable Energy Agency, 2011, Scenarios and Strategies for Africa, paper presented at the IRENA-Africa High-level Consultations, Abu Dhabi, 8-9 July 2011.

Kaplinsky, Raphael \& Dirk Messner, 2008, Introduction: The Impact of Asian Drivers on the Developing World, World Development 36 (2), 197-209. 
Li, Wanxin, Jieyan Liu \& Duoduo Li, 2012, Getting Their Voices Heard: Three Cases of Public Participation in Environmental Protection in China, Journal of Environmental Management 98, 65-72.

Liu, Yi \& Sun Xiuyan, 2006, Interview with Zhou Shengxian: A Good Administrative Chief Would Better to Do a Good Job in Environmental Protection and Not to Pollute, Beijing News, Xinhua Net, People's Daily, 20 April 2006.

Lüdemann, Cord, 2011, Renewable Energy Promotion in Developing Countries - The Case of South Africa, The China Monitor 67, 10-17.

MOF/Ministry of Finance, Ministry of Commerce, National Development and Reform Commission, Ministry of Industry and Information, Ministry of Environmental Protection, State Administration for Industry and Commerce, and General Administration of Quality Supervision and Quarantine, 2009, Measures on Replacing the Used Electronic Home Appliances with the New Ones (家电以旧换新实施办法), Beijing, Government of the People's Republic of China.

MOF/Ministry of Finance \& MOST/Ministry of Science and Technology, 2009, Guidelines on the Management of Fiscal Subsidies on Energy Efficient Vehicles and Vehicles Using New Energy Sources (Trial Implementation) (节能与新能源汽车示范推 广财政补助资金管理暂行办法), Beijing, Government of the People's Republic of China.

MOF/Ministry of Finance \& NDRC/Ministry of Finance and National Development and Reform Commission, 2007, Guidelines on the Management of Fiscal Subsidies on Promoting LED Products (Trial Implementation), 高效照明产品推广财政补贴资金 管理暂行办法, Beijing, Government of the People's Republic of China.

Nature, 2009, Raising the Standards, Nature 459, 1033-1034.

Obi, Cyril, 2008, Enter the Dragon? Chinese Oil Companies and Resistance in the Niger Delta, Review of African Political Economy,35, 417-434.

OECD/Organisation for Economic Co-operation and Development, 2009, Ensuring Environmental Compliance: Trends and Good Practices, Paris, OECD.

Ruppel, Oliver \& Sanita van Wyk, 2011, Climate Change Effects on Human Security in Africa: Environmental Migration - A Case for Human Rights?, The China Monitor $66,10-17$.

Shaw, William, 2012, Will Emerging Economies Repeat Environment Mistakes of their Rich Cousins?, Carnegie Endowment Online, available at http://carnegieendowment .org/2012/03/01/will-emerging-economies-repeat-environmental-mistakes-of-their-r ich-cousins/9zni, last accessed 10 September 2012.

State Council of China, 2009, State Council Decided on Carbon Emission Reduction Targets at the General Committee Meeting, Beijing, State Council of China.

State Council of China, 2011, The 12th Five-year Plan for the Economic and Social Development of the People's Republic of China, Beijing, Xinhua News Agency.

Tilt, Bryan, 2007, The Political Ecology of Pollution Enforcement in China: A Case from Sichuan's Rural Industrial Sector, The China Quarterly 192, 915-932.

World Bank, 2007, Cost of Pollution in China - Economic Estimates of Physical Damage, Washington, DC, World Bank. 
Xie, Dengke, Wenjing Yum \& Zhenhua Xie, 2009, China Insists on Six Principles in Addressing Climate Change, Xinhua News Agency, 26 June 2009.

Xiong, Yan, 2011, Objectives and Principles of the Transformation to Low Carbon Development, 21st Century Economy, 21 February 2011.

Xinhua News Agency, 2009a, China Invested over 10 Billion in Technologies Addressing Climate Change during the 11th Five-year Plan Period, Xinhua News, 12 November 2009.

Xinhua News Agency, 2009b, Xie Zhenhua: Five Major Achievements by China in Addressing Climate Change, Xinhua Net, 26 June 2009.

Yang, Zhangli \& Yongde Ge, 2006, Capacity Building in Local Environmental Governance: Case Study of Nantong City, Beijing, Centre for Industrial Development and Environmental Governance, available at http://166.111.100.15:8081/cms/Reports/56 0 .jhtml, last accessed 2 May 2013.

Zhu, Da \& Jiang Ru, 2008, Strategic Environmental Assessment in China: Motivations, Politics, and Effectiveness, Journal of Environmental Management 88 (4), 615-626.

Zhu, Jianhua, 2011a, Low Carbon City - Baoding Pursued a Different Path for Development and Led the Trend of Green Growth of Cities, People's Daily, 25 August 2011.

Zhu, Tony, 2011b, China Plans to Have 100 New Energy Demonstration Cities by 2015, Business China, 27 April 2011.

Zhu, Zhiqun, 2010, China's New Diplomacy: Rationale, Strategies and Significance, Farnham, Ashgate. 
